\title{
RISK ANALYSIS: CASE HENKEL
}

\author{
Lidija Barjaktarović ${ }^{1}$, Kosana Vićentijević ${ }^{1}$, Ana Vjetrov ${ }^{2}$ \\ ${ }^{1}$ Faculty of Business in Belgrade, Singidunum University, Belgrade, Serbia \\ ${ }^{2}$ Faculty of economics, finance and administration, Singidunum University, Belgrade, Serbia
}

\begin{abstract}
:
Current turbulent economic situation impose on enterprises various risks in everyday activities. The latter emphasize the necessity for early identification, reaction and the usage of contemporary methods related to risk quantification. This was a good basis for development of totally new concept called Enterprise Risk Management (ERM). The paper analyze Henkel globally, and the implementation of ERM on company's example as well. The aim of the paper is to establish the link between ERM concept implementation and the firm's value. Finally, by using Pearson's correlation coefficient and linear regression in statistical software MINITAB the hypothesis related to ERM concept implementation and the firms' value increase has been confirmed. Good organizational structure, with special units designed for risk monitoring and well developed system of internal control, contribute to better ERM implementation, increasing the value for shareholders. However, the concept has been poorly developed in Serbia. Consequently, in the following period it is necessary to raise the awareness related to risk management importance regarding the increase the shareholders' value through risk management not through risk aversion
\end{abstract}

\section{Key words:}

risks,

ERM concept,

organizational structure,

business performance.

This Research Paper was the part of the project "Improvement of Serbian competitiveness in the process of entering to European Union", no. 47028, in the period 2011-2015, financed by Serbian Ministry of science and technological development.

\section{INTRODUCTION}

Contemporary fluctuated economical terms and conditions create many risks in everyday activities to all companies. Accordingly, it has influence on establishing risk management in companies' business i.e. identification, mitigation and control of risks by usage of modern risk management methods. However, successful appliance of modern risk quantification methods includes usage of new technological solutions, and adequate training of all employees in company. Moreover, it is important to understand relevance of risk management in creating value for the company. Finally, it is needed to improve traditional risk management i.e. to introduce systems for evaluation, control, financing and monitoring of all risks in the company in order to increase the value for its shareholders.

All mentioned facts had impact on development of modern risk management concept of the company i.e. Enterprise Risk Management (ERM concept). It is detailed explained in the document called Enterprise Risk Management - Integrated Framework, prepared by COSO (The Committee of Sponsoring Organizations), which members are following organizations: American Association of Accountants, Institute of Internal Auditors, American Institute of Certified Accountants, International Association of Chief Financial Officers, and Institute of Managerial Accountants. Moreover, it is stressed that COSO initiated project together with Price Water House Coopers in order to develop ERM concept which will be used by company's management in order to improve and evaluate performances of the company's.

Subject of this research is appliance of ERM concept on Henkel on global level. The aim of the work is to present how appliance of ERM concept has impact on increase of company's value. It implicates holistic approach to company's risk management. Accordingly the main hypothesis of the work is:
H0: Successful appliance of ERM concept has influence on increasing the company's value.

The research has four chapters. The first chapter is introduction. ERM concept is explained in the second chapter. Within the third chapter the methodology is represented. Consequently, the results of research are presented in the fourth chapter.

\section{ERM CONCEPT}

Current turbulent economic situation impose on enterprises various risks in everyday activities. Moreover, risk represents daily part of life of all economical factors. Barjaktarović (2013) pointed out that risk as science has short history [1]. Accordingly, Đorđević et al. (2012) mentioned that traditional risk management approach meant to delegate responsibilities for risk identification, management and control on the level of particular business functions [5]. It included independent risk management on the level of particular departments, without considering the fact that all risks are connected and they can cause higher damage. However, this approach is inefficient in contemporary business' conditions. Global market trends had impact on development of new concept called Enterprise Risk Management (ERM), initiated by Committee of Sponsoring Organizations (COSO). ERM concept is defined as process initiated by Supervisory and Executive Board of directors, managers and employees, as part of company's strategy in order to provide long term profitable business for the company i.e. to determine the risk appetite of the company.

ERM concept represents improved traditional risk management approach i.e. discipline in estimation, control, financing and monitoring all company's risks in order to increase the value of the company for shareholders [5]. Moreover, all risks are subject of consideration at the same moment in coordi- 
nated and strategically leaded frame [3]. Finally, Baxter et al. (2013) determined the relation between ERM concept, business performances of the company (measured by ROA) and market value of the company, i.e. market has better acceptance of the companies which have better appliance of ERM concept [2]. However, previous researches confirmed that company's announcement of new Chief Risk Officer (CRO) doesn't have impact on increase of company's market value [3]. Before the crisis, there were no relation between appliance of ERM concept and profitability. After the crisis there is strong relation between profitability of financial institutions and appliance of ERM concept. Moreover, it had influence on creating more transparent business of companies, for both the company and all relevant stakeholders.

\section{METHODOLOGY}

The data for research are financial reports of Henkel on group level in the period of 1998 to 2013 available on company's site. All data is expressed in million euro (EUR).

Risks subject of analysis are mentioned in reports of Henkel. Moreover, it is applied Henkel's classification of risks (not $\mathrm{COSO}$ ). The focus of analysis was on business and functional risks.

Price risks and production risks are considered as business risks. Price risk is connected to the price of raw materials which company buys. However, company uses derivatives (futures) for price risk mitigation. Accordingly, nominal value of company's derivates is use for hedging of price, interest and foreign exchange risk and consequently represents one of indicators for managing those business risks.

Production risk means that company doesn't use full production capacity. Moreover, it covers unpredictable conditions for factories' maintenance, employees' training, investment in fixed assets, etc. which have impact on decreased level of production and decreased sales income of Henkel's products. Accordingly, level of profit margin and sales income are taken as indicators of business risks. Furthermore, investments of the company are important for improving production capacities, products' innovations and respecting all safety standards in production process. Consequently, CAPEX (capital expenditure), Investment ratio (\% of sales income and level of investment in research and development) are taken as indicators of business risks. The last indicator covers training of employees.

Financial risks are analyzed in the group of functional risks. Indicator for liquidity risk is level of cash flow generated from business activities of the company. Indicators for credit risk are level of loans in use (they are in the function of selling goods on differed payment) and costs of write offs of accounts receivables. Interest rate risks' indicators are presented in interest rate costs and nominal values of applied derivates. Foreign exchange risks' indicators are effects of exchange rates on cash and nominal value of derivates. Finally, equity risk indicator is $\mathrm{Eq}$ uity ratio (relation between equity and assets).

Pierson's correlation coefficient is used for determining the relation between mentioned indicators i.e. successful appliance of ERM concept on company's value, expressed by market capitalization. correlation coefficient shows that variation of one indicator is followed by movement of other indicator, but it doesn't mean that there is cause relation. If the coefficient has value higher from $+/-0.5$ it means that there is strong positive or negative correlation. Subject of analysis were results with strong relations between indicators. Moreover, authors used the classical multiple regression model

$$
E(Y)=\beta_{0}+\beta_{1} X_{1}+\beta_{1} X_{1} \ldots+\beta_{k-1} X_{k-1}
$$

where $\mathrm{Y}$ is dependent indicator, $\mathrm{X}$ is independent indicator, while coefficients $B$ represents movement of dependent indicator when dependent indicator has movement for one unit. Market capitalization is the dependent indicator in regression equitation. Independent indicators in regression equitation are: level of loans in usage, costs of write offs of accounts receivables (credit risk), costs of interest rate coverage, effects of exchange rates on cash, nominal level of derivates (price, interest rate and foreign exchange risk), equity ratio, sales income, profit margin, investment ratio, investment in research and development, CAPEX (business risks) and cash flow generated from business activities (liquidity risk). It means that there will be attempt to establish relation between risk management and value of the company.

Finally, it is important to say that there will be used statistical softwares SPSS and MINITAB.

\section{RESULTS}

Results related to Pearson's correlation coefficients showed that indicator of market value are positively correlated with risk indicators (correlation above 0.5 ) which are statistically important as well. The strongest correlation is between indicators ratio of coverage interest rate costs and market capitalization. It represents at the same time importance of coverage costs of interest rate and usage of derivatives in limiting losses connected to fluctuations of interest rates. However, indicators of sales income and investment in new trends follow increase of market value. Table 1 represents results of multiple regression model.

The highest percentage of coverage of dependent indicator by independent indicator is visible in the last, forth equitation, where four of six coefficients are statistically important, i.e. confirm very logical results. It means that decreased level of loans to creditors, i.e. lower level of debts, good liquidity and solid coverage of interest rate costs give positive picture to stakeholders, which, consequently, may have impact on price of company's shares. However, it confirms that good risk management has influence on company's value. Research results confirm main hypothesis that successful appliance of ERM concept has impact

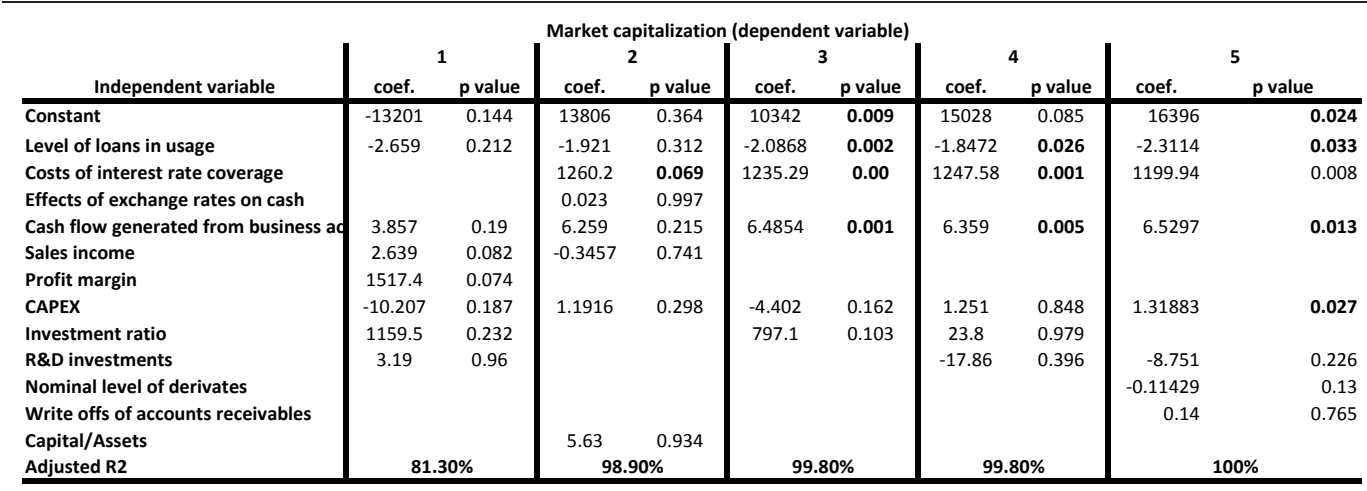

Table 1 Results of regression analysis for the period of 1998 to 2013, where market capitalization represents dependent indicator

[Source: Web site of Henkel, Yearly Reports in the period from 1998 to 2013, available on site: http://www.henkel. com/investor-relations/downloads-archives-11894.htm, date of access 08/29/2014] 
on increase of company's value and it makes positive impression on investors regarding transparency and surety related to company's business. However, appliance of this concept in Serbia is something new and there are a lot of problems in executing best practices of corporate governance in the field of risk management.

Currently, financial institutions - primarily banks are more successful in applying risk management, because their basic job is to accept risk i.e. to estimate profit in accordance with accepted risk. Moreover, implementation of Basel II regulation and experience of banks during the crisis improved risk management and internal audit system. However, other industries are far away from implementation of ERM concept and revealing the necessity for investing a lot of many in IT and proper training of staff, and to be committed to introduce new functions such as risk management, in order to implement it adequatly. Finally, level of awareness and education of employees should be improved in terms of appliance derivates as tool in risk management. Moreover, awareness of people in using risk management should be improved, because risk should be managed, not avoid. Crucial thing is to recognize chances, and to minimize the risks in order to improve financial performances of the company, which was the aim of this paper research.

\section{CONCLUSION}

Contemporary uncertainty in company's daily business is the cause of implementing ERM concept i.e. early identification, reaction and appliance of modern methods for risk quantification in daily business of the company. However, the success of usage of modern methods for risk quantification is based on modern technological solutions and adequate staff (continuer education - long life education). ERM concept is in the function of long-run profitable business of the company and increased value of the company for shareholders.

The main hypothesis of research is confirmed by usage of linear regression in statistical software MINITAB i.e. there is relation between ERM concept implementation and increased value for shareholders. Good organizational structure, with adequate risk management organizational units and well established internal control system, make easier appliance of ERM, which lead to creating the value for shareholders. However, appliance of ERM is in early phases. In the future, all activates of relevant international and local bodies should be in the function of increase of risk management awareness in order to recognize chances to raise the value for shareholders i.e. to be proactive in recognizing possible threatens.

\section{REFERENCES}

[1] Barjaktarović L. (2013), Upravljanje rizikom, 4. dopunjeno izdanje, Univerzitet Singidunum, Beograd.

[2] Baxter R., Bedard J., Hoitash R., Yezegel A. (2013), Enterprise Risk Management Program Quality: Determinants, Value Relevance and the Financial Crisis, Contemporary Accounting Research, Vol.30 No.4, pp. 1264-1295

[3] Beasley M, Pagach D., Warr R. (2008), Information conveyed in hiring announcements of senior executives overseeing enterprise-wide risk management processes, Journal of Accounting, Auditing and Finance 23: pp. 311-332.

[4] Dash W., Olson D. (2010), Enterprise risk management: a DEA VaR approach in vendor selection, International Journal of Production Research, Vol. 48, pp. 4919-4932.

[5] Đorđević M., Krstić J. (2012), Interna kontrola i upravljanje rizikom preduzeća od tradicionalnog do revidiranog COSO modela. Ekonomske teme, pp. 151-166.

[6] Site COSO, Enterprise Risk Management-Integrated Framework (2004), [available on site http://www.coso.org/documents/COSO_ERM_ExecutiveSummary.pdf]

[7] Site Henkel, Group management report, [available on site http://annualreport.henkel.com/group-management-report/ risks-and-opportunities-report/risk-management-system/]

[8] Site Henkel, Annual reports for the period of 1998 to 2013 [available on site http://www.henkel.com/investor-relations/downloads-archives-11894.htm]

\title{
ANALIZA UPRAVLJANJA RIZICIMA NA PRIMERU KOMPANIJE HENKEL
}

\author{
Lidija Barjaktarović ${ }^{1}$, Kosana Vićentijević ${ }^{2}$, Ana Vjetrov ${ }^{3}$ \\ ${ }^{1}$ Poslovni fakultet u Beogradu, Univerzitet Singidunum, Danijelova 32, Beograd, Srbija, lbarjaktarovic@singidunum.ac.rs \\ ${ }^{2}$ Poslovni fakultet u Beogradu, Univerzitet Singidunum,, Danijelova 32, Beograd, Srbija, kvicentijevic@singidunum.ac.rs \\ ${ }^{3}$ Fakultet za ekonomiju, finansije i administraciju - FEFA, Univerzitet Singidunum, Bulevar Zorana Đinđića 44, Beograd, Srbija, avjetrov@fefa.edu.rs
}

\section{Apstrakt:}

Današnji turbulentni ekonomski uslovi nameću preduzećima mnoštvo rizika sa kojima se susreću u svakodnevnom poslovanju. U prvi plan se stavlja značaj koncepta ranog identifikovanja, reagovanja, kao i upotreba savremenih metoda kvantifikacije rizika u svakodnevnom poslovanju jedne kompanije. Pomenuto je dovelo do razvijanja novog koncepta nazvanog upravljanje rizikom preduzeća (Enterprise Risk Management - ERM koncept). U radu je analizirano poslovanje kompanije Henkel, na globalnom nivou, kao i primena samog koncepta na primeru pomenute kompanije. Cilj rada je da pokaže kako primena ERM koncepta doprinosi uvećanju vrednosti preduzeća. Na kraju, u radu je potvrđena polazna hipoteza, primenom Pirsonovog koeficijenta korelacije i linearne regresije $u$ statističkom softveru MINITAB. Dobra organizaciona struktura, sa adekvatnim organizacionim jedinicima, zaduženim za praćenje, kvantifikaciju rizika i dobro uspostavljen sistem interne kontrole doprinosi boljem upravljanju i primeni ERM koncepta, što utiče na stvaranje vrednosti za akcionare. Međutim, primena ovog koncepta je još uvek u početnoj fazi. Stoga je u narednom periodu potrebno raditi na podizanju svesti o upravljanju rizicima, kao šansi da se poveća vrednost za akcionare, što se može ostvariti suočavanjem sa rizicima, a ne njihovim izbegavanjem.

\section{Ključne reči:}

rizici,

ERM koncept, organizaciona struktura, poslovne performance. 